\title{
Extradural implantation of sacral anterior root stimulators
}

\author{
D Sauerwein, W Ingunza, J Fischer, H Madersbacher, C E Polkey, G S Brindley, \\ P Colombel, P Teddy
}

\begin{abstract}
A technique for extradural deafferentation of the $S 2$ to $S 5$ segments and extradural implantation of stimulating electrodes is described, and its application to twelve patients with spinal cord lesions is reported. Nine patients use their implants for micturition, and seven are fully continent. The advantages and disadvantages of this technique compared with the more usual intrathecal procedure are discussed.
\end{abstract}

The first sacral anterior root stimulators for bladder control in spinal cord injury or disease were implanted in 1976 (1), 1978 (2) and 1979 (4). In these $\mathrm{e}^{2}$ and in the great majority of the 250 or more sacral anterior root stimulators implanted up to now, the electrodes have been placed intrathecally at about the level of the last intervertebral disc. Laminectomy of the first two pieces of sacrum and the fifth and fourth and sometimes the third lumbar vertebra is required.

In October 1982 Tanagho and Schmidt of San Francisco reported at a meeting that they had that year implanted three sacral anterior root stimulators with electrodes placed extradurally through a laminectomy of the sacrum only. Further implantations of the same kind have been done in San Francisco, but the publications ${ }^{34}$ give very little detail, either of technique or of results. ${ }^{\star}$

In September 1986 a patient from Bad Wildungen, FRG, was selected as needing a sacral anterior root stimulator implant and deafferentation of the bladder, but was unsuitable for the standard intrathecal operation because she had previously had oily myelography. The abundant remaining contrast medium that could be seen radiogra- phically in the lumbosacral subarachnoid space made it nearly certain that she had severe arachnoiditis. We therefore decided to attempt ganglionectomy of the 2nd, 3rd and 4th sacral posterior roots with preservation of the anterior roots and implantation of stimulating electrodes. The operation was carried out in December 1986, and was very successful. There have now been twelve operations of this kind; four in Bad Wildungen (patients 1-4), three in Innsbruck (patients 5, 6 and 12), three in London (patients 7, 8 and 10) and one each in Le Mans and Oxford (patients 9 and 11). One of us (GSB) was present at 11 of the 12 operations and assisted at all except those on patients 3, 4 and 12 . We report the technique and results and consider the distinctive applications of the intrathecal and extradural approaches.

\section{Patients}

All patients had spinal cord lesions, and in all of them reflex functions of the sacral segments of the cord were preserved. Details are given in table 1 . Patients $2-10$ and 12 had no voluntary movements and no sensation below the levels shown in table 1 . Patients 1 and 11 retained some sensation but no voluntary movement below their levels.

The lesions were traumatic in patients 3-12. In patient 1 , who has a long and complex medical history, the cause of paraplegia is uncertain. Patient 2 has an intramedullary tumour.

Table 1 also gives the reason for choosing the extradural procedure. In patients 1-7 and 9-12 there was a clear reason. In patient 8 there was not; intrathecal implantation would have been equally practicable.

Patients 7 and 11 had had intrathecal sacral
University Hospital J Fischer

H Madersbacher

The Maudsley

Hospital, London

C E Polkey

G S Brindley

Centre de l'Arche,

Le Mans, France

P Colombel

Radcliffe Infirmary,

Oxford

P Teddy

Correspondence to: G S Brindley, MRC

Neurological Prostheses

Unit, Institute of Psychiatry, De Crespigny Park,

Denmark Hill, London

SE5 8AF, United Kingdom.

Received 31 July 1989.

Accepted 2 January 1990

\section{Table 1 Details of patients}

\begin{tabular}{|c|c|c|c|c|c|c|}
\hline \multicolumn{2}{|c|}{$\begin{array}{l}\text { Patient, } \\
\text { sex }\end{array}$} & \multirow{2}{*}{$\begin{array}{l}\text { Year of } \\
\text { birth } \\
1944 \\
1938 \\
1960 \\
1966 \\
1961\end{array}$} & \multirow{2}{*}{$\begin{array}{l}\begin{array}{l}\text { Year of } \\
\text { injury }\end{array} \\
- \\
\overline{1978} \\
1986 \\
1980\end{array}$} & \multirow{2}{*}{$\begin{array}{l}\begin{array}{l}\text { Level of } \\
\text { lesion }\end{array} \\
\text { T3 } \\
\text { T10/12 } \\
\text { T11 } \\
\text { C6 } \\
\text { T11 }\end{array}$} & \multirow{2}{*}{$\begin{array}{l}\begin{array}{l}\text { Reason for choosing } \\
\text { extradural procedure }\end{array} \\
\text { Previous oily myelography } \\
\text { Severe lumbar scoliosis } \\
\text { Fusion of upper lumbar vertebrae } \\
\text { Unstable lumbar vertebral column } \\
\text { Arachnoiditis seen on attempting intrathecal } \\
\text { SARS }\end{array}$} & \multirow{2}{*}{ 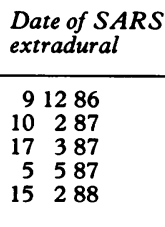 } \\
\hline $\begin{array}{l}1 \\
2 \\
3 \\
4 \\
5\end{array}$ & $\begin{array}{l}\text { Female } \\
\text { Female } \\
\text { Female } \\
\text { Female } \\
\text { Female }\end{array}$ & & & & & \\
\hline $\begin{array}{r}6 \\
7 \\
8 \\
9 \\
10\end{array}$ & $\begin{array}{l}\text { Male } \\
\text { Male } \\
\text { Male } \\
\text { Male } \\
\text { Male }\end{array}$ & $\begin{array}{l}1952 \\
1959 \\
1950 \\
1954 \\
1953\end{array}$ & $\begin{array}{l}1983 \\
1979 \\
1987 \\
1976 \\
1980\end{array}$ & $\begin{array}{l}\text { T5 } \\
\text { T7 } \\
\text { T7 } \\
\text { T4 } \\
\text { T1 }\end{array}$ & $\begin{array}{l}\text { Previous oily myelography } \\
\text { Failure of previous intrathecal SARS } \\
\text { Arbitrary } \\
\text { Previous oily myelography } \\
\text { Arachnoiditis seen on attempting intrathecal } \\
\text { SARS }\end{array}$ & $\begin{array}{rr}16 & 288 \\
15 & 388 \\
8 & 488 \\
6 & 688 \\
29 & 688\end{array}$ \\
\hline $\begin{array}{l}11 \\
12\end{array}$ & $\begin{array}{l}\text { Male } \\
\text { Female }\end{array}$ & $\begin{array}{l}1955 \\
1956\end{array}$ & $\begin{array}{l}1978 \\
1962\end{array}$ & $\begin{array}{l}\mathrm{T} 5 / 7(\mathrm{~S} 1 \mathrm{inc}) \\
\mathrm{T} 6\end{array}$ & $\begin{array}{l}\text { Failure of previous intrathecal SARS } \\
\text { Severe kyphoscoliosis }\end{array}$ & $\begin{array}{rr}3 & 888 \\
15 & 489\end{array}$ \\
\hline
\end{tabular}


anterior root stimulators implanted in February 1983 and August 1986 respectively. In both patients, no posterior roots were cut at the time of implantation. In both, the implants performed imperfectly, residuals being not very low and continence not complete. After intervals of three years and 21 months respectively, both these intrathecal implants developed faults. It would have been possible to repair them, but since deafferentation was also needed, it seemed better to abandon the faulty implants (removing their receiver blocks) and put in new extradural implants.

Patients 1-4 are briefly reported in reference five. Patient 7 is patient 23 of reference two. Patient 9 is patient 3 of reference six. Patients 5 and 6 are two of the four mentioned in the addendum to reference seven.

\section{THE IMPLANT}

This is the same in all patients, except for one detail mentioned below. It has three passive radio receivers and three cables like those shown in fig 1 of reference 2 for the ordinary intrathecal sacral anterior root stimulator. Instead of the electrode "books" of that implant, it has tripoles (a cathode between two anodes) of helical electrodes formed from the flamed ends of the three $90 \%$ platinum $10 \%$ iridium cable wires. The branched cable has its two tripoles in parallel, and is used for the right and left $\mathrm{S} 2$ roots. Of the two unbranched cables, one is usually used for the left $S 3$ and S4, and the other for the right S3 and S4. In the first four implants, all the cables were unbranched and therefore certain roots (in each case roots which gave no bladder pressure on stimulation during the operation) were not provided with implanted electrodes.

\section{SURGICAL TECHNIQUE}

The first three pieces of the sacrum are laminectomised. In all patients in this paper the laminectomy has also included the L5 vertebra. This upward extension of the laminectomy makes the deafferentation, implantation of electrodes, and safe siting of the cables easier, but it is not absolutely necessary.

The termination of the theca and the $S 2$ to S5 segmental nerves are exposed, but are not at first separated from their anterior attachments. The ganglia of S2 to S4 are identified on both sides. It is usually unnecessary, as well as difficult, to identify the ganglion of S5. Deafferentation This is done at the ganglion and immediately cranial to it. It is best to begin with an $\mathrm{S} 2$ segmental nerve, because the deafferentation is easier than for S3 and S4, and the consequences of accidental damage to the anterior root usually less serious. A length of the S2 segmental nerve, extending from the lower boundary of the ganglion to about $4 \mathrm{~mm}$ above its upper boundary is separated from anterior attachments. A $9 \mathrm{~mm}$ longitudinal incision is made in the fibrous sheath of the mobilised segment of nerve. The margins of the sheath are retracted, and gentle blunt dissection of the contents begun. Endoneurial fibrous tissue, though not absent, is present only as fine strands in this region. The anterior root is typically a discrete white parallel-fibred bundle lying anterior to the yellowish ganglion. Cranial to the ganglion, the anterior root is one of 3,4 or 5 white parallel-fibred bundles between which there is little or no crossing of nerve fibres. It is usually the largest bundle, and in all our patients the most anterior. It can be seen to be the only bundle that does not enter the ganglion. Sometimes inspection leaves no doubt about the identity of the anterior root. If there is doubt, however slight, the identity of the anterior root and the bundles into which the posterior root divides must be checked by electrical stimulation. When one bundle has been shown to give appropriate skeletal muscle responses at $1 \mathrm{~V}, 350 \mu \mathrm{s}, 3 \mathrm{~Hz}$ and bladder pressure at $10 \mathrm{~V}, 350 \mu \mathrm{s}, 30 \mathrm{~Hz}$, and the other bundles have been shown not to give such responses at these voltages, the non-responding (posterior) strands must be cut and the responding strand (anterior) carefully preserved.

The deafferentation is done similarly for all six ganglia. It is usually more difficult for S3 and still more difficult for S4. The S5 segmental nerves should be stimulated at $10 \mathrm{~V}$, $350 \mu \mathrm{s}, 30 \mathrm{~Hz}$ to see whether they give bladder pressure. In our experience they give none, or far less than the other roots. If so they should be crushed to interrupt afferent fibres but allow any efferent fibres to the anal sphincter to regenerate. The functional but not anatomical interruption of afferent fibres is probably permanent. ${ }^{8}$ If the S5 segmental nerves give substantial bladder pressure, an attempt can be made to dissect their ganglia.

Implantation of electrodes Attached to each tripolar electrode array close to the cathode is a strip of reinforced silicone rubber sheet $9 \mathrm{~mm}$ wide and about $36 \mathrm{~mm}$ long. One end of this is passed under the appropriate segmental nerve (S2) or nerves (S3 and S4 together). For this purpose it may be necessary to separate an additional length of the S3 or S4 nerve from its anterior attachments. The reinforced silicone rubber strip is then sewn to itself to trap the nerve or nerves. It should be just loose enough to allow a little sliding. The upper and lower anodes should be laid within a few millimetres of the nerve. It is not important whether or not they touch it.

When all the electrodes are in place, the cables are tunnelled through to the receiver site and the block of receivers implanted, as in the ordinary intrathecal operation.

\section{Results}

Further surgical procedures needed Patient 1 suffered a cerebrospinal fluid (CSF) leak, which required surgical repair.

Patient 11 still had reflex urinary incontinence after implantation of his extradural sacral anterior root stimulator, and his implantdriven micturition was unsatisfactory because of detrusor-sphincter dyssynergia. We therefore did a posterior rhizotomy of $S 2$ to $S 5$ at the 
Table 2 Results of operation

\begin{tabular}{|c|c|c|c|c|c|c|c|}
\hline Patient & $\begin{array}{l}\text { Dat } \\
S A \\
\text { extr }\end{array}$ & $\begin{array}{l}\text { te of } \\
R S \\
\text { radural }\end{array}$ & $\begin{array}{l}\text { Present bladder } \\
\text { management } \\
\text { (May 1989) }\end{array}$ & Continence & Cystometry & $\begin{array}{l}\text { Recent residuals } \\
\text { after implant- } \\
\text { driven voiding }\end{array}$ & $\begin{array}{l}\text { Anterior } \\
\text { roots damaged }\end{array}$ \\
\hline 1 & & 1286 & Implant & Fully continent & $\begin{array}{l}\text { Areflexic }(800 \mathrm{ml}) . \text { Normal } \\
\text { compliance }\end{array}$ & $<20 \mathrm{ml}$ & $\begin{array}{l}\text { Left and } \\
\text { right S3 }\end{array}$ \\
\hline 2 & & 287 & $\begin{array}{l}\text { Intermittent } \\
\text { catheter }\end{array}$ & Fully continent & $\begin{array}{l}\text { Areflexic }(800 \mathrm{ml}) . \text { Normal. } \\
\text { compliance }\end{array}$ & . No recent measurement & $\begin{array}{l}\text { Left and } \\
\text { right } S 2\end{array}$ \\
\hline 3 & & 387 & Implant & Fully continent & $\begin{array}{l}\text { Areflexic }(800 \mathrm{ml}) . \text { Normal } \\
\text { compliance }\end{array}$ & $50 \mathrm{ml}$ & $\begin{array}{l}\text { Left S3 and } \\
\text { right S4 }\end{array}$ \\
\hline 4 & 5 & 587 & Implant & Fully continent & $\begin{array}{l}\text { Areflexic }(800 \mathrm{ml}) . \text { Normal } \\
\text { compliance }\end{array}$ & $<20 \mathrm{ml}$ & $\begin{array}{l}\text { Left } S 2 \text { and } \\
\text { S3 }\end{array}$ \\
\hline 5 & & 288 & Implant & Fully continent & $\begin{array}{l}\text { Areflexic }(500 \mathrm{ml}) . \text { Normal } \\
\text { compliance }\end{array}$ & $<20 \mathrm{ml}$ & $\begin{array}{l}\text { Left and } \\
\text { right S3 }\end{array}$ \\
\hline 6 & & 288 & Implant & Fully continent & $\begin{array}{l}\text { Areflexic }(500 \mathrm{ml}) \text {. Normal } \\
\text { compliance }\end{array}$ & $20-50 \mathrm{ml}$ & Left S2 \\
\hline 7 & & 388 & Implant & Slight stress incontinence & $\begin{array}{l}\text { Areflexic }(350 \mathrm{ml}) \text {. Normal } \\
\text { compliance }\end{array}$ & $<20 \mathrm{ml}$ & $\begin{array}{l}\text { Left S3 and } \\
\text { S4 }\end{array}$ \\
\hline 8 & 8 & 488 & Not known & Not known & Not yet done & No recent measurement & $\underset{\text { S4 }}{\text { Right } S 3 \text { and }}$ \\
\hline $\begin{array}{r}9 \\
10\end{array}$ & & $\begin{array}{l}688 \\
688\end{array}$ & $\begin{array}{l}\text { Implant } \\
\text { Indwelling catheter }\end{array}$ & $\begin{array}{l}\text { Slight stress incontinence } \\
\text { No leaks round catheter }\end{array}$ & $\begin{array}{l}35 \mathrm{~cm} \mathrm{H}_{2} \mathrm{O} \text { at } 400 \mathrm{ml} \text { filling } \\
\text { Not yet done }\end{array}$ & $\begin{array}{l}<20 \mathrm{ml} \\
\text { No recent measurement }\end{array}$ & $\begin{array}{l}\text { Right S3 } \\
\text { Right S2, S3 }\end{array}$ \\
\hline 11 & 3 & 888 & Implant & Fully continent ${ }^{\star}$ & $\begin{array}{l}\text { Areflexic }(500 \mathrm{ml}))^{\star} \\
\text { Normal compliance }\end{array}$ & $<20 \mathrm{ml}$ & Left S2 \\
\hline 12 & 15 & 489 & $\begin{array}{l}\text { Implant + abd. } \\
\text { straining }\end{array}$ & Wet at night & $25 \mathrm{~cm} \mathrm{H}_{2} \mathrm{O}$ at $200 \mathrm{ml}$ filling & $\begin{array}{l}80 \text { ml without straining. } \\
\text { Less with straining }\end{array}$ & $\begin{array}{l}\text { Left S3 and } \\
\text { S4 }\end{array}$ \\
\hline
\end{tabular}

^After subsequent posterior rhizotomy at the conus medullaris.

conus medullaris on January 8th 1989 . The very satisfactory result of this procedure will be reported elsewhere.

Patient 12 still has reflex urinary incontinence at night due to a persisting detrusor reflex activity and will need a posterior rhizotomy of $\mathbf{S} 2$ to $\mathbf{S} 5$ at the conus medullaris. Bladder management Before the operation, patients 1,3 and 10 had suprapubic $(1,3)$ or urethral (10) indwelling catheters. All the rest were incontinent, including those $(2,4)$ who practised intermittent catheterisation. Patients $5,7,8,9$ and 11 used condom urinals.

At present, patients $1,3,4,5,6,7,9,11$ and 12 use implant-driven micturition. Only patient 12 supplements it with abdominal straining. The residual volume is less than $50 \mathrm{ml}$ in all patients, and less than $20 \mathrm{ml}$ in most of them (table 2). Among these patients, numbers 7 and 9 have slight stress incontinence but no reflex incontinence, and the rest are fully continent. Patient 2 does intermittent self-catheterisation and is continent. At present patient 10 has an indwelling urethral catheter (which he had before the operation), but it is likely that he will later use his implant.

The present state of patient 8 , who lives in Nigeria, is unknown. When last in England (June 1988) he was continent and using his implant.

Cystometry Before the operation, patient 5 had an underactive reflex bladder of large capacity. Reflex contractions, besides being difficult to trigger, were poorly sustained, and reflex micturition left a large residual volume. All the other patients had over-active reflex bladders, and patients $1,4,9$ and 10 had deficient bladder compliance.

Post-operative cystometric examination showed areflexia and normal compliance in patients 1-7 and 11. Patient 9 still has a minor defect of compliance. Patient 12 still shows detrusor reflex activity post-operatively, but this is much less than before the operation. Post-operative cystometry has not yet been done in patients 8 and 10 .

Damage to anterior roots In the established intrathecal procedure for implanting sacral anterior root stimulators, there is a risk of damaging some of the anterior roots. Such damage could be detected in 23 of the first 50 such patients. The frequency of damage has been lower among patients who have had the intrathecal operation more recently, ${ }^{5-7}$ but it seems fair to compare the first 12 patients with extradural implantation with early cases of intrathecal implantation. Using the same criteria of diagnosis, some root damage was found in all 12 patients with extradural implantation. The probability of finding 23 out of 50 and 12 out of 12 in two random samples from the same population is less than $1 \%$ (Chi-squared with Yates's correction), so the difference should be considered statistically significant.

Damage to some anterior roots need not make an implant unusable. The implants of all our patients except numbers 2,10 and 12, were usable one week after the operation. In patients 1, 3 and 4 the residuals were large at first, and reached their present satisfactory low values only after some months, during which the responses of the bladder to stimulation through the implant slowly improved. Presumably this improvement depended on regeneration of the damaged fibres, as similar improvement has often been observed in patients with intrathecal sacral anterior root stimulators. ${ }^{126}$

Leakage of CSF Leakage of CSF should not occur after a strictly extradural procedure, and in patients 2-12 none occurred. However, in patient 1 the dura was opened. It was sutured, but a leak occurred later, and needed secondary surgical repair.

\section{Discussion}

Patients 1-7, 9 and 11 have clearly benefited from their operations, and they are pleased with the results. Patient 12 pre-operatively was constantly wet day and night. She now remains dry during the day by electro-micturition every 3-4 hours, but is often wet at night. Future 
benefit is likely after a planned posterior rhizotomy $\mathrm{S} 2$ to $\mathrm{S} 5$ at the conus medullaris. Although patient 10 has not benefited to date, future improvement is likely.

The operation is thus a potentially successful one, which can be recommended for patients who are suitable for a sacral anterior root stimulator, but in whom the standard intrathecal procedure would be risky because of arachnoiditis or instability of the lumbar vertebral column.

Should the extradural procedure replace the intrathecal even for patients for whom there are no special risk factors for the intrathecal operation? We list below the factors relevant to this question.

Length of the operation The time required to expose the ganglia extradurally is on average slightly less than that required to expose the roots intrathecally. The time required to separate the ganglia from the anterior root bundles is always greater, often substantially so, than that required to separate the anterior from the posterior roots intrathecally. The time required to close the wound is always less for the extradural procedure.

Taking these three differences together, the total time is likely to be only slightly shorter for extradural than for intrathecal implantation, for a surgeon with similar experience of both procedures.

Risk of post-operative spinal deformity This must be lower for the extradural procedure. However, even for the intrathecal procedure, present evidence suggests that if patients under 18 years of age or with known instability or scoliosis are excluded, it is so small a risk as to be almost negligible.

Risk of leakage of cerebrospinal fluid This must be lower for the extradural procedure, but may not be zero. A pouch of subarachnoid space often extends to within $10 \mathrm{~mm}$ of an $\mathrm{S} 2$ ganglion, and it may come so close that a thorough separation of the ganglion from the anterior root risks opening this pouch.

Risk of failing to deafferent the S2-S5 segments completely Empirically, there is no evidence for a difference between the two procedures in this respect. In patients 11 and 12 of this series we failed to deafferent completely, and in patient 9 a slight incompleteness of deafferentation is suspected, but in the other nine patients it seems that we succeeded. This is about the same proportion of incomplete deafferentation as occurs in the intrathecal procedure.

Nevertheless, we think that the risk of incomplete deafferentation may prove to be greater with the extradural procedure. Intrathecally, there is normally no connective tissue binding the anterior and posterior root together except the arachnoid sheath that is of necessity divided when each root is separated from the next higher and next lower. The roots are freely mobile, and the length over which anterior and posterior roots can be separated is several centimetres, enough to make separate electrical stimulation of the anterior and posterior roots easy and free from the risk of stimulation of other structures by the spread of current. Extradurally, connective tissue normally binds the ganglion and posterior root to the anterior root and all three to the fibrous sheath. Only about $10 \mathrm{~mm}$ of this sheath can be mobilised if risk to its blood supply is to be avoided. Electrical stimulation of the ganglion and posterior root only, or of the anterior root only, to confirm their identity, is difficult because of the short length available.

Risk of damaging anterior roots The theoretical considerations that make us suspect a higher risk of incomplete deafferentation in the extradural procedure point equally to a higher risk of damaging the anterior roots; and here the empirical results ( 12 out of 12 with damage, as against 23 out of 50 with damage) confirm the theoretical expectation.

When should one use the extradural procedure? The clearest indication is in those few patients, invariably male, in whom it has already been decided that no deafferentation will be done. The extradural procedure is then quicker than the intrathecal, does less damage to bones and muscles, and carries a low risk of CSF leak.

Known arachnoiditis and known instability of the lumbar vertebral column are good indications for the extradural procedure, as is the failure of a sacral anterior root stimulator previously implanted intrathecally if this failure is due to a cable fracture occurring close to the vertebral column.

In other patients, our view is that the intrathecal procedure should be preferred. This view will be changed if future experience with extradural implantation proves to be very favourable.

Patient 10, since December 1989 , uses his implant. He is nearly continent and had a residual of $30 \mathrm{ml}$ on 9 April 1990

*The San Francisco group has now published an informative paper in The Journal of Urology 1989;142:340-5.

1 Brindley GS, Polkey CE, Rushton DN. Sacral anterior root stimulators for bladder control in paraplegia. Paraplegia 1982;20:365-81.

2 Brindley GS, Polkey CE, Rushton DN, Cardozo L. Sacral anterior root stimulators for bladder control in paraplegia: the first 50 cases. J Neurol Neurosurg Psychiatry 1986; 94:1104-14.

3 Schmidt RA. Advances in genitourinary neurostimulation. Neurosurgery 1986;18:1041-4.

4 Tanagho EA, Schmidt RA. Electrical stimulation in the clinical management of the neurogenic bladder. Journal of Urology 1988;140:1331-9.

5 Sauerwein D. Funktionelle Elektrostimulation (FES) der Harnblase. Erste Erfahrungen mit sakraler Deafferentation (SDAF) und Vorderwurzelstimulation (SARS) nach Brindley in Deutschland. Verhandlungsberichte der Deutschen Gesellschaft für Urologie 1987;39:595-7.

6 Egon G, Colombel P, des Roseaux F, Philippi R, Herlant M. Electrostimulation des racines sacrées anterieures chez le paraplégique. A propos de 13 observations. Annales des Réadaptation et de Medicine physique 1989;32:47-57.

7 Madersbacher H, Fischer J, Ebner A. Anterior sacral root stimulator (Brindley): experiences especially in women with neurogenic urinary incontinence. Neurourology and Urodynamics 1988;7:593-601.

8 Brindley GS. The actions of parasympathetic and sympathetic nerves in human micturition, erection and seminal emission, and their restoration in paraplegic patients by implanted electrical stimulators. Proc $R$ Soc Lond 1988;B235:111-20. 